\title{
ВПЛИВ МЕЗЕНХІМАЛЬНИХ СТОВБУРОВИХ КЛІТИН НА ПЕРЕБІГ ІМУННОГО ПРОЦЕСУ В ЩУРІВ 3 ГОСТРИМ ПАРОДОНТИТОМ
}

Вступ. Методи регенеративної терапії починають широко використовувати в медицині. Лікування пародонтиту є складним завданням стоматології, тому відбувається пошук новітніх методів, які були б есрективними за чієї патології.

Мета дослідження - вивчити вплив стовбурових клітин на стан клітинної та гуморальної ланок імунітету за умов експериментального пародонтиту.

Методи дослідження. Дослідження проводили на білих безпородних щурах-самцях масою 180-200 2. Пародонтит викликали шляхом уведення в тканини ясен ліпополісахариду по 40 мікролітрів (1 мг/мл) через день протягом 14 діб. Через 1, 7, 14 і 21 доби після останнього його введення щурів декапітували під тіопенталовим наркозом (50 мг/к2). Контролем слугував матеріал від інтактних тварин. Отримували мезенхімальні стовбурові клітини (МСК) у вагітних самок орієнтовно на 21-24-ту доби вагітності. Для одержання життєздатних МСК використовували ферментний метод. Культивування здійснювали в $\mathrm{CO}_{2}$-інкубаторі за температури $37^{\circ} \mathrm{C}$ та концентрації $\mathrm{CO}_{2}-5 \%$. Стовбурові клітини вводили щурам у ділянку ясен разовою ін'єкцією з розрахунку 1 млн клітин на 1 кг маси тіла. Для максимального збереження життєздатності клітин вводили МСК протягом 30 хв після отримання суспензії. Клітинну (CD4+, CD8+, CD3+, CD20+) ланку імунітету досліджували імунофрлуоресцентним методом за допомогою моноклональних антитіл до CD4+-, CD8+-, CD3+- і CD20+-антигенів щура, кон'югованих із фрлуоресцеїн ізотіоціанатом (FITC) виробництва "Beckman Coulter" (США). Імунореактивність організму вивчали за вмістом сироваткових імуноглобулінів класів A, M, G методом твердофразового імунофрерментного аналізу за допомогою набору реагентів "еBioscience, Inc" із використанням аналізатора "StatFax". Отримані циоррові дані обробляли методом варіаційної статистики. Достовірність відмінностей порівнюваних параметрів між різними вибірками визначали з використанням t-критерію Стьюдента (при нормальному розподілі результатів) чи Манна - Уітні (в разі розподілу, що не був нормальним).

Результати й обговорення. За умов моделювання гострого пародонтиту продукування сироваткових імуноглобулінів значно зростало на початкових етапах експерименту з подальшим зниженням до 21-ї доби. При введенні МСК воно було менш інтенсивним, ніж у тварин без корекції. Вміст CD4+-клітин у щурів з гострим пародонтитом достовірно підвищувався на початкових етапах з подальшим зниженням до 21-ї доби. Після введення МСК він був меншим і на 1-шу добу складав 130,8 \% від показника здорових тварин, що, відповідно, становило 88,6 \% від рівня щурів, яким корекції не проводили. До 21-ї доби вміст CD4+-клітин продовжував знижуватись і достовірно не відрізнявся від такого у тварин без патології. Подібною була динаміка рівня CD8+-клітин, однак підвищення було меншим, ніж CD4+-клітин. Динаміка регуляторного індексу CD4+/CD8+ вказувала на достовірне зростання у тварин з гострим пародонтитом у ранні терміни з подальшим зниженням до 21-ї доби. Вміст CD3+- та CD20+-клітин у сироватці крові щурів з гострим пародонтитом на 1-шу добу достовірно перевищував показники інтактних тварин 3 подальшим зниженням до 21-ї доби. Корекція із застосуванням МСК супроводжувалась менш інтенсивним зростанням рівня CD3+- та CD20+-клітин.

Висновки. У тварин з гострим пародонтитом спостерігають достовірне зростання рівня CD4+-лімороцитів, порушення співвідношення основних субпопуляцій лімсроцитів (CD4+ i CD8+), що супроводжується достовірним підвищенням імунорегуляторного індексу, а також порушення фрункціональності гуморальної ланки імунної системи, що проявляється дисбалансом імуноглобулінів у кров'яному руслі та зниженням резистентності гуморальної ланки імунної системи. Застосування МСК суттєво вирівнює спричинений патологічним процесом дисбаланс імунної системи, сприяючи нормалізації імунорегуляторного індексу та основних класів імуноглобулінів.

КЛЮЧОВІ СЛОВА: гострий пародонтит; запальний процес; імунологічна реактивність; мезенхімальні стовбурові клітини.

ВСТУП. Захворювання пародонта посідають друге місце у світі за поширеністю серед стоматологічних захворювань і мають тенденцію до

(с) Г. Т. Бігуляк, А. І. Довгалюк, І. М. Кліщ, М.-М. О. Стецевич, 2021. повсюдного розповсюдження незалежно від віку, статі й місця проживання пацієнтів.

Функціональні порушення зубо-щелепної системи, як наслідок ураження пародонтитом, розвиваються в 5 разів частіше, ніж при усклад- 
неннях карієсу [1]. В середньому 85 \% працездатного населення потребує пародонтологічної допомоги, при цьому частота потреби в лікуванні пародонтиту за зверненням посідає четверте місце після карієсу та його ускладнень [2]. Такі дані свідчать про гостру потребу в участі фрахівців різного стоматологічного профрілю у забезпеченні комплексного лікування пародонтиту та есрективної реабілітації таких хворих. Чинні схеми лікування цієї патології та сучасні технології не завжди дозволяють досягти бажаного результату і повноцінної реабілітації таких пацієнтів [3, 4]. Несвоєчасне звернення та неефективне симптоматичне лікування пародонтиту в 50 \% клінічних випадків призводять до швидкої втрати груп зубів у працездатної категорії пацієнтів, що потребує значних затрат для відновлення втраченої жувальної фрункції $[2,5]$. Проведення комплексного лікування даного захворювання на основі розробленого індивідуалізованого плану лікування з адекватним вибором об'єму терапевтичних, хірургічних і ортопедичних заходів за показаннями дає можливість отримати клінічний результат та довгострокову ремісію [1, 6]. Такий підхід визначає потребу в постійному пошуку нових методів та засобів лікування пародонтиту, які можна включити в план комплексного лікування [7-9].

Генералізовані хвороби пародонта супроводжуються змінами імунних механізмів захисту ротової порожнини [10] та проявляються у вигляді неухильно прогресуючого дистросрічно-запального процесу, що з віком призводить до повного руйнування міжзубних кісткових перетинок, рухомості та втрати зубів. На сьогодні доведено важливу роль місцевого та системного імунітету у виникненні й розвитку хронічних запальних захворювань пародонта [11, 12]. Наразі отримано переконливі результати, які доводять, що саме імунні порушення визначають хронічний рецидивний перебіг захворювання і зумовлюють властиву йому резистентність до проведеного лікування [13]. Однак дані про характер змін імунної системи у хворих, які страждають від хронічного пародонтиту, досить суперечливі. Так, одні автори вказують на значну роль вторинного імунодесріциту та автосенсибілізації організму пацієнтів, на тлі яких прогресують хронічні запальні захворювання пародонта, інші - на порушення клітинної та гуморальної ланок імунної системи [11-15]. Тому актуальними є дослідження, спрямовані на вивчення імуногенезу хронічних запальних захворювань пародонта. У зв'язку з цим, подальше вивчення порушень імунної реактивності в даної категорії пацієнтів з метою створення нових ефрективних схем комплексного лікування $€$ актуальним.
Останнім часом у літературі все частіше стали використовувати термін "регенеративна медицина". Підстава для цього - досягнення сучасної біології та медицини у вивченні стовбурових клітин, які надають широкі можливості для розвитку трансплантації клітин і тканин при різних патологічних процесах [16-20]. Мезенхімальні стовбурові клітини (МСК) наявні в різних тканинах організму, в тому числі й у кістковому мозку, жировій тканині, шкірі. Вони мають великий регенеративний потенціал і здатні транссрормуватися в різні типи тканин організму. Крім того, стовбурові клітини проявляють виражені імуносупресивні властивості та можуть пригнічувати срункції різних імунних клітин, особливо Т-лімфоцитів, кілерних і дендритних клітин. Ці властивості вже використовують у клініці для гальмування автоімунних реакцій і реакцій трансплантата проти хазяїна. Показано, що імуносупресія стовбурових клітин досягається завдяки синтезу таких гуморальних фракторів, як цитокіни, індоламін-2,3-діоксигеназа, оксид азоту тощо [21, 22].

Однак, незважаючи на значні досягнення експериментальної і клінічної медицини у вивченні стовбурових клітин, залишається невирішеною низка питань, зокрема щодо клінічного патогенетично обґрунтованого їх використання при запально-деструктивних процесах кісткової тканини [23].

Мета дослідження - вивчити вплив стовбурових клітин на стан клітинної та гуморальної ланок імунітету за умов експериментального пародонтиту.

МЕТОДИ ДОСЛІДЖЕННЯ. Дослідження виконували на білих безпородних щурах-самцях масою 180-200 г, отриманих з віварію Тернопільського національного медичного університету імені І. Я. Горбачевського МОЗ України, відповідно до вимог Правил проведення робіт з використанням експериментальних тварин. Щури перебували на повноцінному раціоні віварію 3 вільним доступом до води. Есрективність корекції з використанням стовбурових клітин вивчали на моделі пародонтиту, викликаного шляхом введення ліпополісахариду в тканини ясен по 40 мікролітрів (1 мг/мл) через день протягом 14 діб. Через 1, 7, 14 і 21 доби після останнього його введення щурів декапітували під тіопенталовим наркозом (50 мг/кг). Контролем слугував матеріал від інтактних тварин [24].

Отримували МСК у вагітних самок орієнтовно на 21-24-ту доби вагітності. Після евтаназії із застосуванням тіопенталу з виділених плодів забирали пуповинні канатики, відмивали їх від крові стерильним буфрерним розчином HBSS 3 додаванням 1 \% пеніциліну-стрептоміцину. Далі 
3 метою дисоціації клітинної маси та отримання життєздатних МСК використовували ферментний метод. Для цього зразки тканини подрібнювали скальпелем на фррагменти розміром 0,52,0 мм³ , переносили у центрифужні пробірки 3 2 мл ростового середовища DMEM/F12Advanced і 0,2 мл колагенази I в концентрації 0,075 мг/мл та перемішували, не допускаючи фрлотації. Пробірки з первинним матеріалом та колагеназою інкубували в термобані за температури $37^{\circ} \mathrm{C}$ упродовж 70 хв, ретельно перемішуючи кожні 15 хв. Після ферментації у пробірки додали по 4 мл ростового середовища, піпеткували і центрифугували 5 хв при 300 g. Процедуру повторювали двічі. Отриманий осад ресуспендували в 7 мл DMEM/F12 Advanced з додаванням $10 \%$ ембріональної сироватки телят та висаджували в культуральні фрлакони. Культивування здійснювали в $\mathrm{CO}_{2}$-інкубаторі за температури $37^{\circ} \mathrm{C}$ та концентрації $\mathrm{CO}_{2}-5$ \%. Для введення МСK 3 культурального фрлакона з 90 \% конорлюентом міогенних МСК відбирали кондиційне середовище і промивали клітини буферним розчином HBSS (Gibco). 3 метою відкріплення клітин від дна культурального фрлакона використовували орерментний препарат "Tryple" (Gibco) та інкубували 5 хв при $37^{\circ} \mathrm{C}$. Дію дисоціюючого розчину нейтралізували кондиційним середовищем. Далі клітинну суспензію переносили у центрифужну пробірку й осаджували МСК упродовж 8 хв при 1700 об./хв. Отриманий осад розчиняли в 1 мл розчину HBSS і повторно відцентрифуговували клітини за тих самих умов. Після цього осад розчиняли у фрізрозчині, одержану клітинну суспензію профрільтровували через сито з діаметром пор 100 мкм і підраховували кількість виділених клітин за допомогою гемоцитометра з використанням вітального барвника - трипанового синього. Щурам вводили стовбурові клітини в ділянку ясен разовою ін'єкцією з розрахунку 1 млн клітин на 1 кг маси тіла. Для максимального збереження життєздатності клітин вводили МСК протягом 30 хв після отримання суспензії.

Клітинну (CD4+, CD8+, CD3+, CD20+) ланку імунітету досліджували імунофрлуоресцентним методом за допомогою моноклональних антитіл до CD4+-, CD8+-, CD3+- і CD20+-антигенів щура, кон'югованих із фрлуоресцеїн ізотіоціанатом (FITC) виробництва "Beckman Coulter" (США).

Стан гуморальної ланки імунної системи організму вивчали за вмістом сироваткових імуноглобулінів (Ig) класів A, M, G методом твердофразового імунофрерментного аналізу за допомогою набору реагентів "еBioscience, Inc" із використанням аналізатора "StatFax".

Отримані цифрові дані обробляли методом варіаційної статистики. Достовірність відмінностей порівнюваних параметрів між різними вибірками визначали 3 використанням t-критерію Стьюдента (при нормальному розподілі результатів) чи Манна - Уїтні (в разі розподілу, що не був нормальним). Достовірними вважали відмінності при р<0,05 [25].

РЕЗУЛЬТАТИЙ ОБГОВОРЕННЯ. У ТабЛИЦі 1 наведено результати досліджень вмісту імуноглобулінів у сироватці крові тварин з пародонтитом та за корекції МСК. Як свідчать ці дані, на 1-шу добу гострого пародонтиту продукування сироваткових імуноглобулінів класу А значно зростало і становило 169 \% від рівня щурів без змодельованої патології, а до 7-ї доби від моменту моделювання патологічного процесу показник дещо зменшувався та складав 140,2 \% від норми, однак усе ж достовірно відрізнявся від рівня здорових тварин. У подальшому продукування IgA ще більше знижувалось і становило на 14-ту добу 134,4 \%, а на 21-шу - 127,1 \% від рівня щурів, яким патологічного процесу не моделювали. За умов уведення МСК продукування IgА було менш інтенсивним, ніж у тварин без корекції. Зокрема, на 1-шу добу показник

Таблиця 1 - Показники гуморальної ланки імунної системи у щурів з гострим пародонтитом

\begin{tabular}{|c|c|c|c|c|}
\hline \multirow{2}{*}{\multicolumn{2}{|c|}{ Група тварин }} & \multicolumn{3}{|c|}{ "Показник } \\
\hline & & $\lg \mathrm{A}$, г/л & $\operatorname{lgM}$, г/л & $\operatorname{lgG}$, г/л \\
\hline \multicolumn{2}{|l|}{ Без патології } & $3,58 \pm 0,08$ & $1,72 \pm 0,04$ & $15,40 \pm 0,12$ \\
\hline \multirow{4}{*}{$\begin{array}{l}\text { Гострий } \\
\text { пародонтит }\end{array}$} & 1-ша доба, n=8 & $6,05 \pm 0,10^{\star}$ & $3,11 \pm 0,07^{*}$ & $18,70 \pm 0,19 *$ \\
\hline & 7-ма доба, n=8 & $5,02 \pm 0,12^{\star}$ & $2,72 \pm 0,06^{*}$ & $19,60 \pm 0,12^{*}$ \\
\hline & 14-та доба, n=8 & $4,81 \pm 0,11^{*}$ & $2,44 \pm 0,05^{\star}$ & $23,80 \pm 0,11^{*}$ \\
\hline & 21-ша доба, n=8 & $4,55 \pm 0,12^{\star}$ & $2,16 \pm 0,08^{*}$ & $32,20 \pm 0,16^{*}$ \\
\hline \multirow{4}{*}{$\begin{array}{l}\text { Гострий } \\
\text { пародонтит+МСК }\end{array}$} & 1-ша доба, n=8 & $5,86 \pm 0,09 * \#$ & $2,57 \pm 0,08^{\star \#}$ & $16,90 \pm 0,12^{\#}$ \\
\hline & 7-ма доба, n=8 & $4,94 \pm 0,11^{*}$ & $2,25 \pm 0,06^{\star \#}$ & $18,50 \pm 0,14^{\star *}$ \\
\hline & 14-та доба, n=8 & $4,48 \pm 0,09 * \#$ & $1,92 \pm 0,05^{\text {*\# }}$ & $19,20 \pm 0,12^{\star \#}$ \\
\hline & 21-ша доба, n=8 & $4,12 \pm 0,06^{\star \#}$ & $1,78 \pm 0,06^{\#}$ & $19,8 \pm 0,13^{\star \#}$ \\
\hline
\end{tabular}

Примітки. Тут і в таблиці 2.

1. * - достовірність різниці показників щурів з гострим пародонтитом відносно тварин без змодельованої патології.

2. \#- достовірність різниці показників щурів з гострим пародонтитом, яким проводили корекцію МСК, відносно тварин з гострим пародонтитом, яким корекції не проводили. 
складав 163,7 \% від рівня здорових щурів, що, відповідно, становило 96,9 \% від рівня тварин, яким корекції не проводили. На 7-му добу вміст IgА складав 137,9 \% від норми і 98,4 \% від рівня тварин 3 пародонтитом без корекції. На 14-ту добу показник IgА відносно щурів без змодельованої патології становив 125,1% від рівня тварин без змодельованої патології, однак щодо щурів без корекції він дещо зростав порівняно із 7-ю добою - 93,1 \%. До 21-ї доби вміст IgА складав 115,1 \% від норми і 90,5 \% від рівня тварин, яким корекції не проводили.

Подібну тенденцію спостерігали і стосовно сироваткових імуноглобулінів класу М. Зокрема, вміст IgM у сироватці крові щурів з гострим пародонтитом на 1-шу добу після моделювання патологічного процесу становив 180,8 \% від аналогічного показника інтактних тварин 3 подальшим зниженням до 21-ї доби, коли він складав 125,6 \% від рівня щурів, яким пародонтиту не моделювали. Корекція із застосуванням МСК також супроводжувалась зростанням вмісту IgM, проте менш вираженим, ніж у тварин без корекції. Зокрема, на 1-шу добу спостереження показник був на 49,4 \% вищим від норми і достовірно не відрізнявся від аналогічного показника щурів без корекції, до 21-ї доби це збільшення становило 3,4% відносно інтактних тварин.

За умов експериментального гострого пародонтиту вміст імуноглобулінів класу $G$ у сироватці крові перевищував показник здорових щурів у 1,2 раза на 1-шу добу від моменту моделювання патології. До 7-ї доби досліджуваний показник дещо зріс і становив 127,3 \% від рівня інтактних тварин. До 21-ї доби відзначали подальше збільшення вмісту IgG, і він складав 209,1 \% від норми. На 1-шу добу спостереження рівень IgG у сироватці крові щурів, яким проводили корекцію із застосуванням МСК, становив 109,7 \% від аналогічного показника тварин без змодельованої патології, що, однак, було достовірно більшим, ніж у щурів без корекції. Цю ж тенденцію відмічали і до завершення експерименту - на 21-шу добу показник складав 128,5 \% від норми і 61,5 \% від рівня тварин без корекції.
У таблиці 2 наведено результати досліджень клітинної ланки імунітету. Як свідчать ці дані, на 1-шу добу з моменту моделювання гострого пародонтиту вміст CD4+-клітин значно зростав і становив 147,6 \% від аналогічного показника щурів без змодельованої патології, а до 7-ї доби він дещо знижувався і складав 130,3 \% від норми, однак усе ж достовірно відрізнявся від рівня здорових тварин. У подальшому вміст CD4+-клітин ще більше зменшувався і становив на 14-ту добу 118,5 \%, а на 21-шу - 108,4 \% від рівня щурів, яким патологічного процесу не моделювали. На 1-шу добу після введення МСК вміст CD4+-клітин складав 130,8 \% від показника здорових тварин, що, відповідно, становило 88,6 \% від рівня щурів, яким корекції не проводили. На 7-му добу спостерігали подальше зниження вмісту CD4+-клітин - 119,9 \% від норми і 92 \% від рівня тварин без корекції. На 14-ту добу вміст CD4+-клітин відносно щурів без змодельованої патології ще більше зменшувався і складав 109,5 \%, однак щодо тварин без корекції він дещо зростав порівняно із 7-ю добою - 92,5 \%. До 21-ї доби вміст CD4+-клітин продовжував знижуватись і становив 101,7 \% від норми та 93,9 \% від рівня щурів, яким корекції не проводили.

Аналогічну тенденцію спостерігали і стосовно рівня CD3+-клітин. Зокрема, вміст CD3+-клітин у сироватці крові щурів з гострим пародонтитом на 1-шу добу становив 142,6 \% від аналогічного показника інтактних тварин з подальшим зниженням до 21-ї доби, коли він складав 106,8 \% від рівня щурів, яким пародонтиту не моделювали. Корекція із застосуванням МСК супроводжувалась менш інтенсивним зростанням вмісту CD3+-клітин. Зокрема, на 1-шу добу спостереження показник був на 24,5 \% вищим від норми і достовірно не відрізнявся від аналогічного показника щурів без корекції, до 21-ї доби це збільшення складало 7,1% відносно інтактних тварин.

За умов експериментального гострого пародонтиту вміст CD20+-клітин у сироватці крові перевищував показник здорових щурів у 1,7 раза.

Таблиця 2 - Показники клітинної ланки імунної системи у щурів з гострим пародонтитом

\begin{tabular}{|c|c|c|c|c|c|c|}
\hline \multirow{2}{*}{\multicolumn{2}{|c|}{ Група тварин }} & \multicolumn{5}{|c|}{ Показник } \\
\hline & & CD4+ & CD8+ & CD4+/CD8+ & CD3+ & CD20+ \\
\hline \multicolumn{2}{|l|}{ Без патології } & $39,45 \pm 1,09$ & $23,35 \pm 0,35$ & $1,69 \pm 0,01$ & $61,37 \pm 1,21$ & $22,17 \pm 0,36$ \\
\hline \multirow{4}{*}{$\begin{array}{l}\text { Гострий } \\
\text { пародонтит }\end{array}$} & 1-ша доба, n=8 & $58,22 \pm 1,26^{*}$ & $32,74 \pm 0,98^{*}$ & $1,78 \pm 0,02^{*}$ & $87,54 \pm 1,37^{*}$ & $36,57 \pm 0,61^{*}$ \\
\hline & 7-ма доба, n=8 & $51,42 \pm 1,11^{*}$ & $28,66 \pm 1,01^{*}$ & $1,79 \pm 0,07^{*}$ & $82,23 \pm 1,18^{*}$ & $39,44 \pm 0,82^{*}$ \\
\hline & 14-та доба, n=8 & $46,74 \pm 1,16^{*}$ & $26,32 \pm 0,61^{*}$ & $1,77 \pm 0,05^{\star}$ & $78,14 \pm 1,22^{*}$ & $34,12 \pm 0,97^{*}$ \\
\hline & 21-ша доба, n=8 & $42,75 \pm 1,14$ & $25,63 \pm 0,52$ & $1,68 \pm 0,09$ & $65,57 \pm 1,09$ & $28,52 \pm 0,53$ \\
\hline \multirow{4}{*}{\begin{tabular}{|l} 
Гострий \\
пародонтит+ \\
МСК
\end{tabular}} & 1-ша доба, n=8 & $51,61 \pm 1,01^{* \#}$ & $30,46 \pm 0,91^{*}$ & $1,69 \pm 0,06^{\#}$ & $76,44 \pm 1,11^{\text {*\# }}$ & $35,42 \pm 0,28 *$ \\
\hline & 7-ма доба, $n=8$ & $47,31 \pm 1,08^{\star \#}$ & $26,28 \pm 0,34^{*}$ & $1,80 \pm 0,08^{*}$ & $74,73 \pm 1,21^{\star \#}$ & $36,27 \pm 0,44^{\text {*A }}$ \\
\hline & 14-та доба, n=8 & $43,22 \pm 1,15^{\#}$ & $25,17 \pm 0,42$ & $1,72 \pm 0,06^{\#}$ & $70,93 \pm 1,14^{\star \#}$ & $33,18 \pm 0,28 *$ \\
\hline & 21-ша доба, n=8 & $40,16 \pm 0,95^{\#}$ & $24,22 \pm 0,45$ & $1,66 \pm 0,05$ & $65,76 \pm 0,98$ & $28,14 \pm 0,22^{*}$ \\
\hline
\end{tabular}


До 14-ї доби він дещо знижувався і складав 153,9 \% від рівня інтактних тварин. До 21-ї доби відзначали подальше зменшення вмісту CD20+-клітин, і показник становив 128,6 \% від норми. На 1-шу добу спостереження рівень CD20+-клітин у сироватці крові щурів, яким проводили корекцію із застосуванням МСК, складав 159,7 \% від аналогічного показника тварин без змодельованої патології, що, однак, було достовірно меншим, ніж у щурів без корекції, $-96,9 \%$. Цю ж тенденцію відмічали і до завершення експерименту-на 21-шу добу показник становив 126,9 \% від норми та 98,7 \% від рівня тварин без корекції.

Аналогічною була динаміка рівня CD8+-клітин. У тварин, яким моделювали пародонтит, їх вміст достовірно зростав на 1-шу добу спостереження в 1,4 раза. До 7-ї доби концентрація цього продукту знижувалась і становила 122,7 \% від норми. У подальшому вона продовжувала зменшуватись, і до 14-ї доби показник перебував на рівні $112,7 \%$, а до 21-ї - 99,4 \% від норми. За умов уведення MCK вміст CD8+-клітин знижувався. Зокрема, на 1-шу добу показник складав 130,4 \% від рівня здорових тварин, що, відповідно, становило 93,0 \% від рівня щурів, яким корекції не проводили. На 7-му добу спостерігали подальше зменшення вмісту CD8+-клітин 112,5 \% від норми і 91,7 \% від рівня тварин без корекції. На 14-ту добу вміст CD8+-клітин відносно щурів без змодельованої патології ще більше знижувався і складав 107,8 \%, однак щодо тварин без корекції він дещо зростав порівняно із 7-ю добою-95,6 \%. До 21-ї доби рівень CD8+-клітин значно підвищувався порівняно із 14-ю добою - 172,5 \%.

Подібну тенденцію спостерігали і стосовно динаміки регуляторного індексу CD4+/CD8+. Зокрема, у щурів з гострим пародонтитом на 1-шу добу він становив 106,5 \% від аналогічного показника інтактних тварин з подальшим зниженням до 21-ї доби, коли показник складав 99,4 \% від рівня щурів, яким пародонтиту не моделювали. На 1-шу добу спостереження індекс CD4+/CD8+ у тварин, яким проводили корекцію із застосуванням МСК, становив $100 \%$ від аналогічного показника щурів без змодельованої патології, що, однак, було достовірно меншим, ніж у тварин без корекції, $-93,9$ \%. На 21-шу добу показник складав 53,8 \% від норми і 54,2 \% від рівня щурів без корекції.

На сьогодні імунорегуляторний індекс оцінюють, зіставляючи з фразою імунної відповіді. У період розпалу клінічних проявів запального процесу він сягає високих значень за рахунок великого відсоткового вмісту Т-хелперів (CD4+Т-клітин). У період реконвалесценції показник знижується у зв'язку зі зростанням рівня CD8+Т-клітин. Порушення такої закономірності свідчить про неадекватність імунної реакції та про можливість хронізації процесу через неповну ерадикацію збудника.

ВИСНОВКИ. У тварин з гострим пародонтитом спостерігають достовірне зростання рівня CD4+-лімфоцитів, порушення співвідношення основних субпопуляцій лімфоцитів (CD4+ i CD8+), що супроводжується достовірним підвищенням імунорегуляторного індексу, а також порушення фуннціональності гуморальної ланки імунної системи, що проявляється дисбалансом імуноглобулінів у кров'яному руслі та зниженням резистентності гуморальної ланки імунної системи. Застосування МСК суттєво вирівнює спричинений патологічним процесом дисбаланс імунної системи, сприяючи нормалізації імунорегуляторного індексу та основних класів імуноглобулінів.

\section{СПИСОК ЛІТЕРАТУРИ}

1. Грудянов А. И. Заболевания пародонта / А. И. Грудянов - М. : Медицинское инсрормационное агентство, 2009. - 334 с.

2. Ковалевский А. М. Лечение пародонтита : практ. руководство / А. М. Ковалевский. - М. : МИА, 2010. $160 \mathrm{c}$.

3. Алимский А. В. Организационные аспекты пародонтологической стоматологической помощи населению / А. В. Алимский // Экономика и менеджмент в стоматологии. - 2011. - № 3 (35). - С. 20-21.
4. Дмитриева Л. А. Пародонтология: национальное руководство / под ред. Л. А. Дмитриевой. - М. : ГЭОТАР-Медиа, 2013. - 712 с.

5. Консилиум как путь к дифрференцированному подходу при лечении пациентов с заболеваниями пародонта / Н. М. Спивак, Е. А. Леонтьева, С. С. Григорьев [и др.] // Проблемы стоматологии. - 2008. № 3. - С. 33-37.

6. Белоклицкая Г. Ф. Клинико-патогенетическое обоснование дифреренцированной фрармакотерапии 
генерализованного пародонтита : автореф. дисс. на соискание учен. степени д-ра мед. наук / Г. Ф. Белоклицкая. - К., 1996. - 32 с.

7. Белоклицкая Г. Ф. Современный взгляд на классификации болезней пародонта / Г. Ф. Белоклицкая // Современная стоматология. - 2007. № 3. - С. 59-64.

8. Терапевтична стоматологія : підручник : у 4 т. / [М. Ф. Данилевський, А. В. Борисенко, А. М. Політун та ін.] ; за ред. А. В. Борисенка. - К. : Медицина, 2008. - T. 3. -614 c.

9. Мащенко И. С. Новые аспекты патогенеза и лечения генерализованного пародонтита / И. С. Мащенко, А. В. Самойленко // Вісн. стоматології. -2002. № 1. - C. 12-15.

10. Герелюк В. І. Вплив стану імунної системи на перебіг генералізованого пародонтиту / В. І. Герелюк, О.В.Довганич // Актуальні проблеми сучасної медицини. - 2013. - 13, вип. 3. - С. 22-25.

11. Акопян Г. В. О местных иммунных механизмах поражения зубов и пародонта при периодической болезни / Г. В. Акопян // Стоматология. - 1998. - № 5. C. 4-7.

12. Ипатова Е. В. Особенности местного иммунитета при воспалительных заболеваниях пародонта у жителей Европейского севера / Е. В. Ипатова В. П. Зеновский, А. Г. Дьячкова // Росс. стомат. журн. 2007. - № 2.

13. Бабаджанян Г. С. Состояние местных защитных фракторов полости рта у больных пародонтитом в динамике лечения : автореф. дисс. на соискание учен. степени канд. мед. наук / Г. С. Бабаджанян. - М., 1983. -23 c.

14. Лепилин А. В. Некоторые механизмы возникновения и прогрессирования воспалительных заболеваний пародонта на фроне гастроэзофрагеальной ресрлюксной болезни / А. В. Лепилин, М.А.Осадчук, Н. В. Булкина // Росс. стомат. журн. - 2004. - № 5. C. 34-36.

15. Евстигнеев И. В. Исследование микросрлоры полости рта и оценка местного иммунитета / И. В. Ев- стигнеев // Клініч. імунологія. Алергологія. Інфектологія. - 2013. - № 4 (63). - С. 26-31.

16. Болезни пародонта. Патогенез, диагностика, лечение / А. С. Григорьян, А. И. Грудянов, Н. А. Рабухина, О. А. Фролова. - М. : МИА, 2004. - 320 с.

17. Мазур И. П. Некоторые аспекты патогенеза резорбции альвеолярного гребня при генерализованном пародонтите / И. П. Мазур, В. В. Поворознюк // Пародонтология. - 1999. - № 3. - С. 19-23.

18. Иванов В. С. Заболевания пародонта / В. С. Иванов. - М. : МИА, 1998. - 122 с.

19. Данилевский Н. Ф. Заболевания пародонта / Н. Ф. Данилевский, А. В. Борисенко. - К. : Здоров'я, 2000. - 461 c.

20. Кухарчук А. Л. Стволовые клетки: эксперимент, теория, клиника. Эмбриональные, мезенхимальные, нейральные и гемопоэтические стволовые клетки / А. Л. Кухарчук, В. В. Радченко, В. М. Сирман. - Черновцы : Золоті литаври, 2004. - 505 с.

21. Шумаков В. И. Достижения и перспективы развития трансплантологии и искусственных органов в России / В. И. Шумаков // Вестн. трансплантологии и искусственных органов. - 2005. - № 3. - С. 6-9.

22. Денисов В. К. Особенности современного этапа развития трансплантологии в Украине / В. К. Денисов // Матеріали III з"їзду трансплантології України. Донецьк, 2004. - С. 14-19.

23. Докторов А. А. Морфофрункциональная характеристика эндоста в связи с проблемой ремоделирования кости / А. А. Докторов, Пак Гван Чор // Арх. патологии. - 1998. - 60, № 5. - С. 19-23.

24. Моисеева Е. Г. Метаболический гомеостаз и иммунная реактивность организма в динамике воспаления в тканях пародонта (экспериментальное исследование) : автореф. дисс. на соискание учен. степени д-ра мед. наук / Е. Г. Моисеева. -М., 2008. - 45 с.

25. Лапач С. Н. Статистические методы в медико-биологических исследованиях с использованием Excel / С. Н. Лапач, А. В. Чубенко, П. Н. Бабич. - К. : Морион, 2000. - 320 с.

\section{REFERENCES}

1. Hrudianov, A.Y. (2009). Zabolevanyia parodonta [Periodontal disease]. Moscow: Medytsynskoe informatsyonnoe agentstvo [in Russian].

2. Kovalevskyi, A.M. (2010). Lechenye parodontita [Periodontitis treatment]. Moscow: Izd-vo "MYA" [in Russian].

3. Alymskyi, A.V. (2011). Organyzatsyonnye aspekty parodontologicheskoy stomatologicheskoy pomoshch naseleniyu [Organizational aspects of periodontal dental care for the population]. Ekonomika $i$ menedzhment $v$ stomatologii - Economics and Management in Dentistry, 3 (35), 20-21 [in Russian].

4. Dmytryeva, L.A. (2013). Parodontologiya [Periodontics]. Moscow: Natsyonalnoe rukovodstvo, GEOTARMedia [in Russian].

5. Spyvak, N.M., Leonteva, E.A., Hryhorev, S.S. (2008). Konsylium kak put k dyfferentsyyrovannomu podkhodu pri lechenii patsyentov s zabolevaniyamy parodonta [Consilium as a way to a differentiated approach in the treatment of patients with periodontal disease]. Problemy stomatologii - Dentistry Problems, 3, 33-37 [in Russian].

6. Beloklytskaia, H.F. (1996). Kliniko-patogenetycheskoe obosnovanye dyfferentsyrovannoy farmakoterapii generalizovannogo parodontita [Clinical and pathogenetic substantiation of differentiated pharmacotherapy of generalized periodontitis]. Doctor's Extended abstract [in Russian].

7. Beloklytskaia, H.F. (2007). Sovremennyy vzglyad na klassifikatsii bolezney parodonta [A modern view on the classification of periodontal diseases]. Sovremennaya stomatologiya - Modern Dentistry, 3, 59-64 [in Russian].

8. Danylevskyi, M.F., Borysenko, A.V., Politun, A.M., \&Antonenko, M.Yu. (2008). Terapevtychna stomatolohiia. Tom 3 [Therapeutic dentistry, Vol. 3]. Kyiv: Medytsyna [in Ukrainian]. 
9. Mashchenko, Y.S., \& Samoilenko, A.V. (2002). Novyeaspekty patogenezailecheniya generalizovannoggo parodontita [New aspects of pathogenesis and treatment of generalized periodontitis]. Visn. Stomatolohii - Dentistry Bulletin [in Russian].

10. Hereliuk, V.I., \& Dovhanych, O.V. (2013). Vplyv stanu imunnoi systemy na perebih heneralizovanoho parodontytu [Influence of the immune system to the relocation of generalized periodontitis]. Aktualni problemy suchasnoi medytsyny - Urgent Problems of Modern Medicine, 13 (3) [in Ukrainian].

11. Akopian, H.V. (1998). O mestnykh immunnykh mekhanizmakh porazheniya zubov i parodonta pry peryodycheskoy bolezny [About local immune mechanisms of teeth and periodontal disease in case of periodic illness]. Stomatologiya - Dentistry, 5 [in Russian].

12. Ypatova, E.V., Zenovskyi, V.P., \& Diachkova, A.H. (2007). Osobennosty mestnogo immuniteta pry vospalytelnykh zabolevaniyakh parodonta u zhyteley Evropeyskogo severa [Features of local immunity in inflammatory periodontal diseases in residents of the European North]. Rossyiskyy stomatologicheskyy zhurnal - Russian Dentistry Journal, 2 [in Russian].

13. Babadzhanian, H.S. (1983). Sostoyanye mestnykh zashchytnykh faktorov polosty rta u bolnykh parodontitom $v$ dinamike lecheniya [The state of local protective factors of the oral cavity in patients with periodontitis in the dynamics of treatment]. Candidate's Extended abstract [in Russian].

14. Lepylyn, A.V., Osadchuk, M.A., \& Bulkyna, N.V. (2004). Nekotorye mekhanyzmy voznyknoveniya i progressirovaniya vospalytelnykh zabolevaniy parodonta na fone gastroezofagealnoy reflyuksnoy bolezni [Some mechanisms of the onset and progression of inflammatory periodontal diseases against the background of gastroesophageal reflux disease]. Rossyiskiy stomatologicheskyy zhurnal - Russian Dentistry Journal, 5 [in Russian].

15. Evstyhneev, Y.V. (2013). Issledovanye mikroflory polosty rta i otsenka mestnogo immuniteta [Study of the microflora of the oral cavity and assessment of local immunity]. Klinichna imunolohiia. Alerholohiia. Infektolohiia - Clinical Immunology. Allergology. Infectology, 4 (63) [in Russian].

16. Hryhorian, A.S., Hrudianov, A.Y., Rabukhyna, N.A., \& Frolova, O.A. (2004). Bolezni parodonta. Patogenez, diagnostika, lechenye [Periodontal disease. Pathogenesis, diagnosis, treatment]. Moscow: MIA [in Russian].
17. Mazur, Y.P., \& Povorozniuk, V.V. (1999). Nekotorye aspekty patogeneza rezorbtsii alveolyarnogo grebnya pri generalizovannom parodontite [Some aspects of the pathogenesis of resorption of the alveolar ridge in generalized periodontitis]. Parodontologiya Periodontics, 3 [in Russian].

18. Yvanov, V.S. (1998). Zabolevaniya parodonta [Periodontal disease]. Moscow: MYA [in Russian].

19. Danylevskyi, N.F., \& Borysenko, A.V. (2000). Zabolevaniya parodonta [Periodontal disease]. Kyiv: Zdorovia [in Russian].

20. Kukharchuk, A.L., Radchenko, V.V., \& Sirman, V.M. (2004). Embryonalnye, mezenkhimalnye, neyralnye $i$ gemopoetycheskye stvolovye kletky [Stem cells: experiment, theory, clinic. Embryonic, mesenchymal, neural and hematopoietic stem cells]. Chernivtsi: Zoloti lytavry [in Russian].

21. Shumakov, V.Y. (2005). Dostyzheniya iperspektivy razvitiya transplantologii $\mathrm{i}$ iskusstvennykh organov $\mathrm{V}$ Rossii [Achievements and prospects for the development of transplantology and artificial organs in Russia]. Vestnik transplantologii $i$ iskusstvennykh organov - Bulletin of Transplantology and Artificial Organs, 3, 6-9 [in Russian].

22. Denysov, V.K. (2004). Osobennosti sovremennogo etapa razvitiya transplantologii v Ukraine [Features of the current stage of development of transplantation in Ukraine]. Materialy III zizdu transplantolohii Ukrainy Materials of the III Transplantation Department of Ukraine. Donetsk [in Ukrainian].

23. Doktorov, A.A. (1998). Morfofunktsyonalnaya kharakterystyka endosta $v$ svyazi s problemoy remodelirovaniya kosti [Morphofunctional characteristics of the endosteum in connection with the problem of bone remodeling]. Arkhiv patologii-Archive of Pathology, 60 (5), 19-23[in Russian].

24. Moyseeva, E.H. (2008). Metabolicheskyy gomeostaz i immunnaya reaktivnost organizma $v$ dinamike vospaleniya $v$ tkanyakh parodonta (eksperymentalnoe issledovanye) [Metabolic homeostasis and immune reactivity of the body in the dynamics of inflammation in periodontal tissues (experimental study)]. Doctor's Extended abstract. Moscow [in Russian].

25. Lapach, S.N., Chubenko, A.V., \& Babych, P.N. (2000). Statisticheskye metody v medyko-biologicheskykh issledovaniyakh s ispolzovanyem Excel [Statistical methods in life sciences research using Excel]. Kyiv: Morion [in Russian].

\section{ВЛИЯНИЕ МЕЗЕНХИМАЛЬНЫХ СТВОЛОВЫХ КЛЕТОК НА ТЕЧЕНИЕ ИММУННОГО ПРОЦЕССА У КРЫС С ОСТРЫМ ПАРОДОНТИТОМ}

\section{Резюме}

Вступление. Методы регенеративной терапии начинают широко использовать в медицине. Лечение пародонтита является сложной задачей стоматологии, поэтому происходит поиск новых методов, которые были бы эфрфективными при этой патологии. 
Цель исследования - изучить влияние стволовых клеток на состояние клеточного и гуморального звеньев иммунитета в условиях экспериментального пародонтита.

Методы исследования. Исследования проводили на белых беспородных крысах-самцах массой 180-200 г. Пародонтит вызывали путем введения в ткани десен липополисахарида по 40 микролитров (1 мг/мл) через день в течение 14 суток. Через 1, 7, 14 и 21 сутки после последнего его введения крыс декапитировали под тиопенталовым наркозом (50 мг/к2). Контролем служил материал от интактных животных. Получали мезенхимальные стволовые клетки (МСК) у беременных самок ориентировочно на 21-24-е сутки беременности. Для получения жизнеспособных МСК использовали фрерментный метод. Культивирование осуществляли в $\mathrm{CO}_{2}$-инкубаторе при температуре $37^{\circ} \mathrm{C}$ и концентрации $\mathrm{CO}_{2}-5 \%$. Стволовые клетки вводили крысам в область десен разовой инъекцией из расчета 1 млн клеток на 1 кट массы тела. Для максимального сохранения жизнеспособности клеток вводили МСК в течение 30 мин после получения суспензии. Клеточное (CD4+, CD8+, CD3+, CD20+) звено иммунитета исследовали иммунофрлуоресцентным методом с помощью моноклональных антител к CD4+-, CD8+-, CD3+- $\mathrm{C}$ CD20+-aнтигенам крысы, конъюгированным с фрлуоресцеин изотиоцианатом (FITC) производства "Beckman Coulter" (США ). Иммунореактивнисть организма изучали по содержанию сывороточных иммуноглобулинов классов A, M, G методом твердофразного иммуноферментного анализа с помощью набора реагентов "eBioscience, Inc" с использованием анализатора "StatFax". Полученные цифровые данные обрабатывали методом вариационной статистики. Достоверность различий сравниваемых параметров между различными выборками определяли с использованием t-критерия Стьюдента (при нормальном распределении результатов) или Манна - Уитни (в случае распределения, который не был нормальным).

Результаты и обсуждение. В условиях моделирования острого пародонтита продуцирование сывороточных иммуноглобулинов значительно росло на начальных этапах эксперимента с последующим снижением до 21-х суток. При введении МСК оно было менее интенсивным, чем уживотных без коррекции. Содержание CD4+-клеток у крыс с острым пародонтитом достоверно повышалось на начальных этапах с последующим снижением до 21-х суток. После введения МСК оно было меньще и на 1-е сутки составляло 130,8 \% от показателя здоровых животных, что, соответственно, составляло 88,6 \% от уровня крыс, которым коррекции не проводили. До 21-х суток содержание CD4+-клеток продолжало снижаться и достоверно не отличалось от такового у животных без патологии. Подобной была динамика уровня CD8+-клеток, однако повышение было меньше, чем CD4+-клеток. Динамика регуляторного индекса CD4+/ CD8+ указывала на достоверное возрастание у животных с острым пародонтитом в ранние сроки с последующим снижением до 21-х суток. Содержание CD3+- и CD20+-клеток в сыворотке крови крыс с острым пародонтитом на 1-е сутки достоверно превышало показатели интактных животных с последующим снижением до 21-х суток. Коррекция с применением МСК сопровождалась менее интенсивным возрастанием уровня CD3+- и CD20+-клеток.

Выводы. У животных с острым пародонтитом наблюдают достоверное возрастание уровня CD4+-лимфроцитов, нарушение соотношения основных субпопуляций лимфоцитов (CD4+ и CD8+), что сопровождается достоверным повышением иммунорегуляторного индекса, а также нарушение функциональности гуморального звена иммунной системы, что проявляется дисбалансом иммуноглобулинов в кровяном русле и снижением резистентности гуморального звена иммунной системы. Применение МСК существенно выравнивает вызванный патологическим процессом дисбаланс иммунной системы, способствуя нормализации иммунорегуляторного индекса и основных классов иммуноглобулинов.

КЛЮЧЕВЫЕ СЛОВА: острый пародонтит; воспалительный процесс; иммунологическая реактивность; мезенхимальные стволовые клетки.

H. T. Bigulyak, A. I. Dovgalyuk, I. M. Klishch, M.-M. O. Stetsevych

I. HORBACHEVSKY TERNOPIL NATIONAL MEDICAL UNIVERSITY

\section{THE INFLUENCE OF MESENCHYMAL STEM CELLS ON THE COURSE OF THE IMMUNE PROCESS IN RATS WITH ACUTE PERIODONTITIS}

\section{Summary}

Introduction. Methods of regenerative therapy are beginning to be widely used in medicine. Treatment of periodontitis is a complex task of dentistry, therefore, there is a search for new methods that would be effective in this pathology.

The aim of the study - to learn the effect of stem cells on the state of cellular and humoral immunity in conditions of experimental periodontitis.

Research Methods. The study was carried out on white out bred male rats weighing 180-200 g. Periodontitis was caused by the introduction of lipopolysaccharide into the gum tissue at 40 microliters (1 $\mathrm{mg} / \mathrm{ml}$ ) every other day 
for 14 days. On days 1, 7, 14, and 21 after the last LPS injection, the rats were decapitated under thiopental anesthesia (50 mg/kg). Material from intact animals served as control. MSCs were obtained from pregnant females, approximately on the $21-24^{\text {th }}$ day of pregnancy. An enzymatic method was used to obtain viable MSCs. The cultivation was carried out in a $\mathrm{CO}_{2}$ incubator at a temperature of $37^{\circ} \mathrm{C}$ and a $\mathrm{CO}_{2}$ concentration of $5 \%$. Stem cells were injected into the gum of rats with a single injection at the rate of 1 million cells per $1 \mathrm{~kg}$ of body weight. To maximize the preservation of cell viability, MSCs were injected within 30 min after the suspension was obtained. Studies of the cellular (CD4+, CD8+, CD3+, CD20+) immune system were performed by immunofluorescence method using monoclonal antibodies to CD4+-, CD8+-, CD3+- and CD20+-antigens of rats conjugated to fluorescein isothiocyanate (FITC) produced by "Beckman Coulter" (USA). Immunoreactivity of the organism was studied by the content of serum immunoglobulins $A, M, G$ by the method of solid-phase enzyme-linked immunosorbent assay using a set of reagents "eBioscience, Inc" using the analyzer "StatFax". The obtained digital data were processed by the method of variation statistics. The significance of differences in the compared parameters between different samples was determined by using the Student's t-test (with a normal distribution of results) or Mann-Whitney (in the case of a distribution that was not normal).

Results and Discussion. Under the conditions of modeling of acute periodontitis, the production of serum immunoglobulins increased significantly in the initial stages of the experiment with a subsequent decrease to the $21^{\text {st }}$ day. Under the conditions of MSC injection, the production of immunoglobulins was less intense than in animals without correction. The level of CD4+ cells in animals with acute periodontitis increased significantly in the initial stages, with a subsequent decrease to the $21^{\text {st }}$ day. After the injection of MSC, the level of CD4+ cells was lower and on the $1^{\text {st }}$ day was $130.8 \%$ of healthy animals, which was $88.6 \%$ of the level of animals that were not corrected. By the day 21, CD4+ cell levels continued to decline and did not differ significantly from animals without pathology. The dynamics of CD8+ cell levels were similar, but the growth was less than that of CD4+. The dynamics of the $C D 4+/ C D 8+$ regulatory index indicates a significant increase in animals with acute periodontitis, with a further decrease to the $21^{\text {st }}$ day The content of CD3+ and CD20+ cells in the serum of animals with acute periodontitis on the $1^{\text {st }}$ day significantly exceeded that of intact animals with a further decrease to the $21^{\text {st }}$ day. The correction with the use of MSCS was accompanied by a less intense increase in the level of CD3+ and CD2O+ cells.

Conclusions. In animals with acute periodontitis there is a significant increase in CD4+ lymphocytes, a violation of the ratio of major subpopulations of lymphocytes (CD4+ and CD8+), accompanied by a significant increase in the immunoregulatory index, and dysfunction of the humoral immune system, manifested by blood imbalance and reducing the resistance of the humoral part of the immune system. The use of MSCs significantly compensates for the imbalance caused by the pathological process of the immune system, contributing to the normalization of the immunoregulatory index and the main classes of immunoglobulins. cells.

KEY WORDS: acute periodontitis; inflammatory process; immunological reactivity; mesenchymal stem

Отримано 16.03.21

Адреса для листування: І. М. Кліщ, Тернопільський національний медичний університет імені І. Я. Горбачевського мОз України, майдан Волі, 1, Тернопіль, 46001, Україна, e-mail: klishch@tdmu.edu.ua. 